\title{
Karyotype Diversity in Three Asparagus L. Species
}

\author{
Suma Akter, Kazi Nahida Begum, Syeda Sharmeen Sultana and \\ Sheikh Shamimul Alam*
}

Department of Botany, University of Dhaka, Dhaka-1000, Bangladesh

Received July 27, 2017; accepted August 25, 2017

\begin{abstract}
Summary Three Asparagus species viz. A. racemosus Willd., A. officinalis L., and A. setaceus (Kunth) Jessop were investigated by cytogenetical and molecular analysis for authentic characterization. The diploid chromosome number $2 n=20$ was found in $A$. racemosus and $A$. setaceus, while, A. officinalis possesses $2 n=22$ chromosomes. Diploid chromosome number $2 n=22$ is the first report for $A$. officinalis. These three species differed in respect of other karyotypic features such as total length of $2 n$ chromosome complements, number of satellites, range of relative lengths, centromeric indices, etc. Some unique CMA- and DAPI-banded chromosomes were found in three species which could be used as marker chromosomes for the respective species. A pair of satellites was observed in A. racemosus after CMA- and DAPI-staining but absent in orcein staining indicating the stain-specific nature of satellites. The chromosomes of three Asparagus species possessed different structural abnormalities such as deletions, tandem duplications, and dispersed distribution of GC- and AT-rich repetitive sequences. This organizational variation of chromosomes was one of the major reasons for karyotype diversification. Four primer combinations were applied for RAPD analysis in three species of Asparagus to find out their genomic relationship. The three species showed several unique bands useful as markers for each species. Therefore, the three Asparagus species could authentically be characterized by conventional and fluorescent karyotype together with RAPD fingerprinting.
\end{abstract}

Key words Fluorescent banding, Karyotype, RAPD, Asparagus L.

The genus Asparagus L. belongs to Liliaceae consisting of about 300 species (Kumar et al. 2016). The plants of this genus are herbaceous, perennial, tender woody shrubs and vines, distributed throughout the tropical and sub-tropical countries of the world (Kumar et al. 2016, Camadro 1994). According to Siddiqui et al. (2007), only four Asparagus L. species were reported from Bangladesh. These are i) A. adscendens Roxb., ii) A. racemosus Willd., iii) A. setaceous (Kunth) Jessop, and iv) A. acerosus Roxb. In Bangladesh, this genus is common in the Sal (Shorea robusta) forests of Gazipur, Mymensingh and Sherpur districts (Siddiqui et al. 2007).

In addition, another edible species namely $A$. officinalis L. was introduced from the USA by Professor (retired) Dr. Mahbubur Rahman Khan, Department of Botany, University of Dhaka to the Botanic Garden, Department of Botany, University of Dhaka. So far this species is not found in any place of Bangladesh (Prof. Dr. Abul Hasan, Department of Botany, University of Dhaka-personal communication).

The species of this genus have gained importance for several purposes such as ornamental plant, vegetables, and as a medicinal herb. The World Health Organization has estimated that $80 \%$ population of developing countries, being unable to afford pharmaceutical drugs, relies

\footnotetext{
* Corresponding author, e-mail: ssalam81@yahoo.com DOI: $10.1508 /$ cytologia. 82.551
}

on traditional medicines, mainly plant based, to sustain their primary health care needs (Singh 2014). The root extracts of the medicinal Asparagus species were found to possess anti-ulcer (Sairam et al. 2003), antioxidant (Siddiqui et al. 2007, Kamat et al. 2000), anti-diarrhoeal (Venkatesan et al. 2005), anti-carcinogenic, immune stimulant and hepato protective activities and also used in nervous disorders, bronchitis, inflammation, dyspepsia (Garabadu and Krishnamurthy 2014).

The increasing demand of the Asparagus species available in Bangladesh for various purposes has caused a serious reduction in native populations due to over harvesting and deforestation. These plants are now considered endangered in its natural habitat and has also been recognized as 'vulnerable' (Siddiqui et al. 2007, Warrier et al. 2001). In this situation, analysis of genetic diversity becomes essential. In order to elucidate genetic diversity and proper conservation, authentic characterization of species are required. For genetic characterization, stable and reliable method must be followed.

Karyotype is a stable and reliable character, which is specific for each specimen. Only a few earlier workers tried to characterize different Asparagus L. species with classical karyotype analysis which were mostly confined to $2 n$ chromosome counting. There are diploid, tetraploid and hexaploid species in the genus, with a basic chromosome number of $\mathrm{X}=10$ (Camadro 1994). Diploid chromosome number $2 n=20,22,24,28,30,40$, 
and 60 chromosomes for different Asparagus L. species were reported earlier by different scientists (Osaka 1938, Sharma and Bhattacharyya 1957, La Cour 1952, Subramanian 1973). Moreover, there is no report even on $2 n$ chromosome counts for the available Asparagus L. species from Bangladesh.

However, conventional karyotype analysis alone is unable to express critically the differences among related species when these may possess similar $2 n$ chromosome number and even other karyotype parameters (Khatun and Alam 2010, Khatun et al. 2011). Minute deletion, inversion, tandem duplication, etc. could not be possible to detect by conventional karyotype analysis. In such a case, modern cytogenetical techniques are necessary for comparative study among related species.

Staining with DNA-base specific banding with fluorochromes such as chromomycin $\mathrm{A}_{3}$ (CMA) and 4'-6 diamidino-2-phenylindole (DAPI) are the effective methods for critical karyotype study such as identification of individual chromosome, determination of amount and site of AT- and GC-rich base pairs in chromosomes, etc. (Schweizer 1976, Alam and Kondo 1995, Sultana et al. 2011).

Molecular marker analysis has become another important tool in studying genetic information and diversity (Bered et al. 2005). DNA fingerprinting by Random Amplified Polymorphic DNA (RAPD) is one of the molecular methods for characterizing different plant specimens. It includes characterization of genetic variability, genome fingerprinting, genome mapping, gene localization, analysis of genome evolution, population genetics, taxonomy, etc. The advantages of RAPD analysis over other methods are its low sample DNA requirement and the high frequency of polymorphic bands (Williams et al. 1990).

In the present study, a combination of cytogenetical and molecular analysis has been carried out for the first time to characterize the three Asparagus species available in Bangladesh viz. A. racemosus Willd., A. officinalis L., and A. setaceus (Kunth) Jessop with the following aims:

i. to make a full strength karyotype for each species.

ii. to compare the fluorescent banding pattern after staining with CMA- and DAPI-fluorochromes and find out the diversity in their karyotypes.

iii. to elucidate the phylogenetic relationship among three Asparagus species on the basis of RAPD banding patterns.

iv. to characterize each species with cytogenetical and molecular markers.

\section{Materials and methods}

Among three Asparagus species, A. setaceus (Kunth) Jessop was collected from a nursery in Agargaon, Dhaka, Bangladesh and the other two spp. namely $A$. racemosus Willd. and A. officinalis $\mathrm{L}$. from the Botanical Garden, Department of Botany, University of Dhaka. These three species were identified by Professor Dr. Md. Abul Hassan, Prof. Salar Khan Herbarium, Department of Botany, University of Dhaka and maintained in the Botanic Garden, Department of Botany, University of Dhaka, Bangladesh.

\section{Cytogenetical study}

Healthy root tips (RTs) were collected and pretreated with 8-hydroxyquinoline $(0.002 \mathrm{M})$ for $2.25 \mathrm{~h}$ at $18-20^{\circ} \mathrm{C}$ followed by $15 \mathrm{~min}$ fixation in $45 \%$ acetic acid at $4^{\circ} \mathrm{C}$. The pretreated RTs were hydrolyzed for $40-45 \mathrm{~s}$ (depending on thickness of root) at $60^{\circ} \mathrm{C}$ in a mixture of $1 \mathrm{NHCl}$ and $45 \%$ acetic-acid $(2: 1)$. The root tips were stained and squashed in 1\% aceto-orcein. For CMAand DAPI banding, Alam and Kondo's (1995) method was used with slight modification. After hydrolysing and dissecting, the materials were squashed with $45 \%$ acetic acid. The cover glasses were removed quickly on dry ice and allowed to air dry for at least $24 \mathrm{~h}$ before study. The air-dried slides were first pre-incubated in McIlvaine's buffer ( $\mathrm{pH} 7.0$ ) for $30 \mathrm{~min}$ followed by Distamycin $\mathrm{A}\left(0.1 \mathrm{mg} \mathrm{mL}^{-1}\right)$ treatment for $10 \mathrm{~min}$. The slides were rinsed mildly in Mcllvaine's buffer supplemented with $\mathrm{MgSO}_{4}(5 \mathrm{mM})$ for $15 \mathrm{~min}$. One drop of CMA $\left(0.1 \mathrm{mg} \mathrm{mL}^{-1}\right)$ was added to the materials for $25 \mathrm{~min}$ in a humid chamber and then rinsed with Mcllvaine's buffer with $\mathrm{MgSO}_{4}$ for $10 \mathrm{~min}$. Slides were mounted in $50 \%$ glycerol and kept at $4{ }^{\circ} \mathrm{C}$ for overnight before observation. These were observed under Nikon (Eclipse 50i) fluorescent microscope with blue violet (BV) filter cassette. For DAPI-staining, after $48 \mathrm{~h}$ of air drying, the slides were first pre-incubated in Mcllvaine's buffer ( $\mathrm{pH}$ 7.0) for $25 \mathrm{~min}$ and treated in Actinomycin $\mathrm{D}\left(0.25 \mathrm{mg} \mathrm{mL}^{-1}\right)$ for $10 \mathrm{~min}$ in a humid chamber. The slides were immersed in DAPI solution $\left(0.01 \mathrm{mg} \mathrm{mL}^{-1}\right)$ for $20 \mathrm{~min}$ and mounted with $50 \%$ glycerol. These were observed under a Nikon (Eclipse 50i) fluorescent microscope with ultra violet (UV) filter cassette.

\section{DNA isolation}

Leaves were harvested and total genomic DNA was extracted by using modified CTAB method (Doyle and Doyle 1987). DNA concentration was quantified through spectrophotometer (Analylikjena, Specord 50, Germany). The A 260/280 readings for DNA samples were 1.6-1.8.

\section{PCR amplification and primer survey}

The PCR reaction mixture for $25 \mu \mathrm{L}$ containing template DNA ( $25 \mathrm{ng}$ ) $2 \mu \mathrm{L}$, de-ionized distilled water $18.8 \mu \mathrm{L}$, Taq buffer A $10 \times$ (Tris with $15 \mathrm{mMMgCl}_{2}$ ) $2.5 \mu \mathrm{L}$, primer $(10 \mu \mathrm{M}) 1.0 \mu \mathrm{L}$, dNTPs $(2.5 \mathrm{mM}) 0.5 \mu \mathrm{L}$, and Taq DNA polymerase $\left(5 \mathrm{U}_{\mu} \mathrm{L}^{-1}\right) 0.2 \mu \mathrm{L}$. PCR amplification was done in an oil-free thermal cycler (Biometra 
UNOII, Germany) for 46 cycles after initial denaturing $94^{\circ} \mathrm{C}$ for $5 \mathrm{~min}$, denaturing at $94^{\circ} \mathrm{C}$ for $1 \mathrm{~min}$, annealing at $34-36^{\circ} \mathrm{C}$ for $30 \mathrm{~s}$, extension at $72^{\circ} \mathrm{C}$ for $3 \mathrm{~min}$, and final extension at $72^{\circ} \mathrm{C}$ for $5 \mathrm{~min}$. Four random primers such as primer OPG-3 (5'-GAGCCC TCC A-3'), primer OPG-6 (5'-GTGCCT AACC-3'), primer OPG-9 (5'-CTGACGTCAC-3'), and primer-3 (5'TGCCGA GCT G-3') were used in the present study for screening.

\section{Gel electrophoresis}

The amplified products were separated electrophoretically on $1 \%$ agarose gel. The gel was prepared using $1.0 \mathrm{~g}$ agarose powder containing ethidium bromide $\left(10 \mathrm{mg} \mathrm{mL}^{-1}\right) 8 \mu \mathrm{L}$ and $100 \mathrm{~mL} 1 \times$ TAE buffer. Agarose gel electrophoresis was conducted in $1 \times \mathrm{TAE}$ buffer at $50 \mathrm{~V}$ and $100 \mathrm{~mA}$ for $1.5 \mathrm{~h}$. DNA ladder $(1 \mathrm{~kb})$ was electrophoresed alongside the RAPD reactions as marker. DNA bands were observed on UV-transilluminator and photographed by a gel documentation system.

\section{Scoring and data analysis}

The PCR products were analyzed after gel electrophoresis. The photographs were critically discussed on the basis of presence (1) or absence (0), size of bands and overall polymorphism of bands. These were carried out for further investigation. The scores obtained using all primers in the RAPD analysis were then pooled for constructing a single data matrix. This was used for estimating polymorphic loci, Nei (1972) gene diversity, genetic distance (D), and constructing a UPGMA (Unweighted Pair Group Method of Arithmetic Means) dendrogram among the specimens, using the computer program "POPGENE" (Version 1.31).

Results and discussion

\section{Karyotype}

In the present study, $A$. racemosus and $A$. setaceus were found to possess $2 n=20$ chromosomes (Figs. 1 and 3). Similar $2 n$ chromosome numbers of these two species were reported by earlier scientists (Osaka 1938, Sharma and Bhattacharyya 1957, Mehra and Malik 1961, Sastry 1981). Besides, different chromosome number for $A$. racemosus such as $2 n=22$ (Subramanian 1973), $2 n=30$ (Thombre 1959), $2 n=40$ (Venkateswarlu and Raju 1957), and $2 n=48$ (Sinha et al. 1972) were also reported. The presence of $2 n=30$ and $2 n=40$ chromosomes indicated triploid and tetraploid nature, respectively. On the other hand, $2 n=22$ and $2 n=48$ indicated aneuploid nature of the plants. $\mathrm{B}$ chromosomes were also reported for this species (Sheidai and Inamdar 1993). However, no B chromosomes were found in any cell in the present investigation. In this study, no numerical changes regarding chromosome number were found in any sample. Therefore, the samples of $A$. racemosus used in this experiment are diploid $(2 n=2 \mathrm{x}=20)$.

On the other hand, in this study $2 n=22$ chromosomes were observed in A. officinalis (Fig. 2). Different $2 n$ chromosome numbers of this species were reported earlier such as $2 n=20$ (Ma et al. 1985, Deng et al. 2012), $2 n=40$ (Krasnikov and Shaulo 1990, Castro et al. 2013), and $2 n=44$ (Kondo et al. 2014). $2 n=22$ chromosomes of $A$. officinalis were not found after reviewing the literature. Therefore, the diploid chromosome number of $2 n=22$ for $A$. officinalis is probably the first record for this species. The present $2 n$ chromosome number suggesting that the specimen used in this study may either be very close to $A$. officinalis or a different cytotype.

In this study, three Asparagus species were found to possess all metacentric chromosomes (Figs. 10-12) with chromosomal length ranging from $0.48-1.58 \mu \mathrm{m}$ (Table 1). The range of chromosomal length for $A$. officinalis was 0.77 to $1.58 \mu \mathrm{m}$. A number of disagreements regarding the chromosomal length and centromeric position were reported earlier for A. officinalis. Mukhopadhyay and Ray (2013) reported the range of chromosomal length as $0.92-5.83 \mu \mathrm{m}$. Deng et al. (2012) classified the $2 n=20$ chromosomes into five long, one medium, and four short pairs. On the other hand, Melo and Guerra (2001) reported longer pairs with $2.4 \mu \mathrm{m}$ (four pairs), medium $1.9 \mu \mathrm{m}$ (two pairs), and short $1.5 \mu \mathrm{m}$ (four pairs).

After compairing the results of Mukhopadhyay and Ray (2013) with Melo and Guerra (2001), it was found that the longer chromosome $(5.8 \mu \mathrm{m})$ mentioned by Mukhopadhyay and Ray (2013) were absent in the karyotypes reported by Melo and Guerra (2001). The present result was compared to that of Melo and Guerra (2001). It was found that the longer chromosome $(2.4 \mu \mathrm{m})$ and the medium chromosome $(1.9 \mu \mathrm{m})$ mentioned by Mello and Guerra (2001) were absent in $A$. officinalis used in this study (Table 1). The chromosomal length around $1.5 \mu \mathrm{m}$ was common in the specimens used in this study and by Melo and Guerra (2001). In addition to the chromosomes of $1.5 \mu \mathrm{m}$ length, nine pairs of chromosomes with around $1 \mu \mathrm{m}$ even less than $1 \mu \mathrm{m}$ length were found in this study (Figs. 10-12, Table 1). The chromosomal length $1 \mu \mathrm{m}$ or less was not reported earlier. Therefore, this category $(1 \mu \mathrm{m}$ or below) in respect of chromosomal length reported first time for $A$. officinalis used in this study.

\section{Satellite}

In this investigation, a pair of satellites was found in chromosome pair IV of $A$. officinalis (Figs. 2, 11, Table 1). Deng et al. (2012) reported one pair of satellites on the short arm of the chromosome pair V. In contrast, four pairs of satellites bearing chromosomes were reported by Rudall et al. (1998) of which three pairs on the long arms and one pair on the short arm. Therefore, the difference regarding the number of satellite bearing chromosomes was observed in different specimens of $A$. 


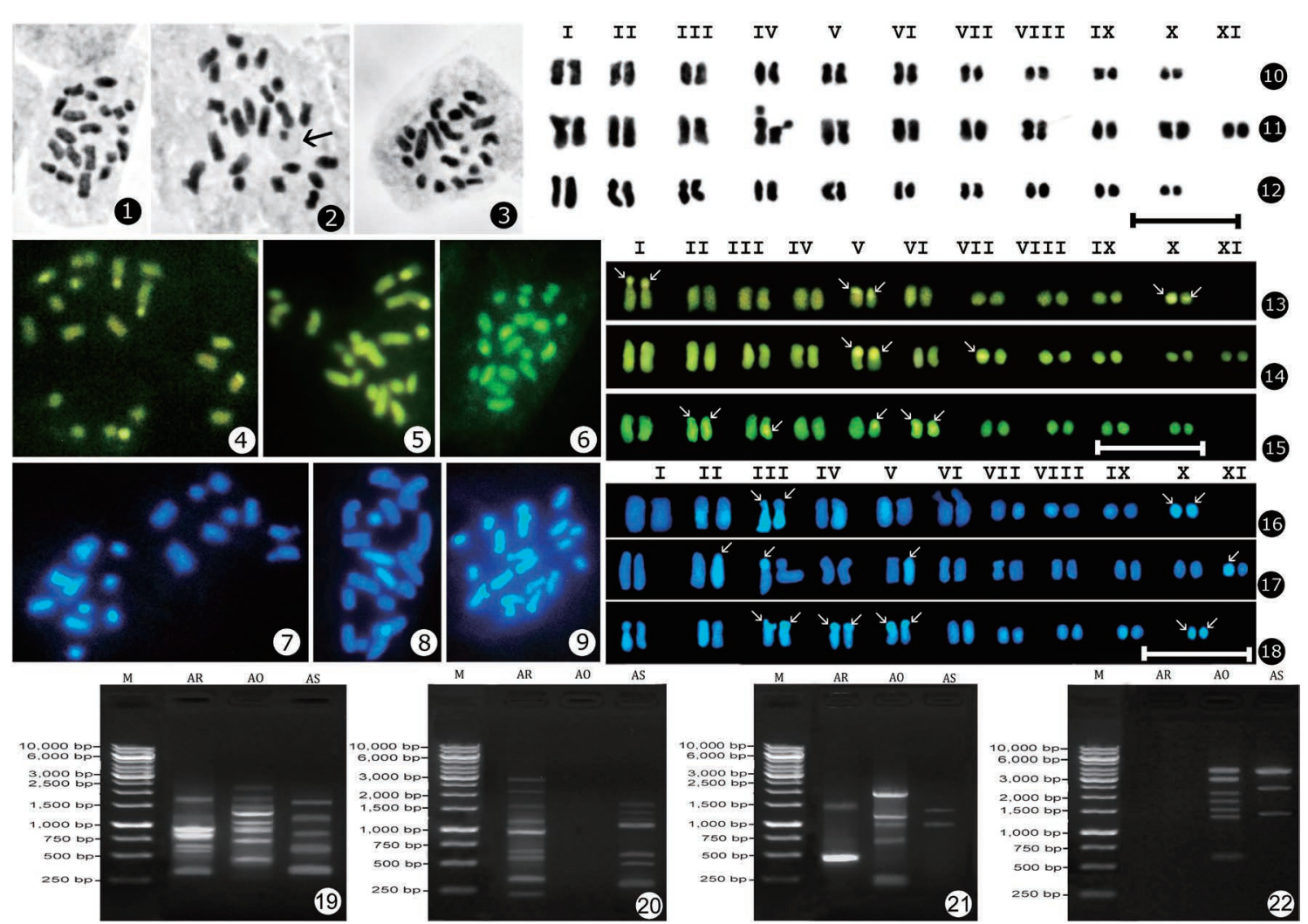

Figs. 1-22. Orcein-, CMA- and DAPI-stained mitotic metaphase and RAPD analysis of three species of Asparagus L. 1. Orcein-stained mitotic metaphase chromosomes of A. racemosus, 2. Orcein-stained mitotic metaphase chromosomes of A. officinalis, 3. Orcein-stained mitotic metaphase chromosomes of A. setaceus, 4. CMA-stained mitotic metaphase chromosomes of A. racemosus, 5. CMA-stained mitotic metaphase chromosomes of A. officinalis, 6. CMA-stained mitotic metaphase chromosomes of A. setaceus, 7. DAPI-stained mitotic metaphase chromosomes of A. racemosus, 8. DAPI-stained mitotic metaphase chromosomes of $A$. officinalis, 9. DAPI-stained mitotic metaphase chromosomes of A. setaceus, 10. Karyotype prepared from orcein-stained mitotic metaphase chromosomes of A. racemosus, 11. Karyotype prepared from orcein-stained mitotic metaphase chromosomes of A. officinalis, 12. Karyotype prepared from orcein-stained mitotic metaphase chromosomes of A. setaceus, 13. Karyotype prepared from CMA-stained mitotic metaphase chromosomes of $A$. racemosus, 14. Karyotype prepared from CMA-stained mitotic metaphase chromosomes of $A$. officinalis, 15. Karyotype prepared from CMA-stained mitotic metaphase chromosomes of A. setaceus, 16. Karyotype prepared from DAPI-stained mitotic metaphase chromosomes of A. racemosus, 17. Karyotype prepared from DAPI-stained mitotic metaphase chromosomes of A. officinalis, 18. Karyotype prepared from DAPI -stained mitotic metaphase chromosomes of A. setaceus, Bar $=10 \mu \mathrm{m}, 19$. RAPD with primer OPG-3, 20. RAPD with primer OPG-6, 21. RAPD with primer OPG-9 and 22. RAPD with primer-3.

officinalis indicating the existence of different cytotypes.

A pair of satellites was found in pair I and VI of $A$. racemosus after CMA- and DAPI-staining, respectively (Figs. 4, 7, 13, 16). However, in orcein staining no satellite was found in this species (Figs. 1, 10). On the other hand, a pair of satellites observed in pair IV of A. officinalis was not found after CMA- and DAPIstaining (Figs. 2, 5, 8, 11, 14, 17). This feature of satellite revealed stain specificity. Alam and Kondo (1995) described the stain specific nature of satellites and some chromosomes in Drosera species. Later different workers reported stain specificity of satellite in few plant species (Khatun and Alam 2010, Khatun et al. 2011, Sultana and Alam 2007, Sultana and Alam 2016). The reason for stain specificity was not clear, however, it may due to the presence of certain DNA sequences, which made the satellites stain specifically. Therefore, the stain specific nature of satellite is a remarkable feature of the

\section{Asparagus karyotype.}

\section{Fluorescent banding}

The number, location, distribution, and intensities of CMA-bands varied in these species. Most of the CMAbands were present at the terminal regions of respective chromosomes in these three Asparagus species (Figs. $4,5,6,13,14,15$, Table 1). In contrast, only one centromeric CMA-band was found in A. racemosus and A. officinalis (Figs. 4, 5, 13, 14). The presence of maximum terminal CMA-bands indicated a tendency of accumulating GC-rich repetitive sequences at the chromosomal ends (Zaman and Alam 2009).

In contrast, a member of chromosome pair X of $A$. racemosus Willd. and both the members of pairs II and VI of $A$. setaceus (Kunth) Jessop were entirely fluoresced with CMA (Figs. 4, 6, 13, 15). In these entirely fluoresced chromosomes, GC-rich repeats were not con- 
Table 1. Comparative orcein-, CMA- and DAPI-karyotype analysis of three species of Asparagus L.

\begin{tabular}{|c|c|c|c|c|c|c|c|c|c|}
\hline Species & $2 n$ & $\begin{array}{c}\text { Range of } \\
\text { chromosomal } \\
\text { length }(\mu \mathrm{m})\end{array}$ & $\begin{array}{c}\text { Total length of } \\
2 n \text { chromosome } \\
\text { complement }(\mu \mathrm{m})\end{array}$ & $\begin{array}{l}\text { Centromeric } \\
\text { formulae }\end{array}$ & $\begin{array}{c}\text { No. of } \\
\text { CMA-bands }\end{array}$ & $\begin{array}{l}\% \text { of } \mathrm{GC}- \\
\text { rich repeats }\end{array}$ & $\begin{array}{c}\text { No. of } \\
\text { DAPI-bands }\end{array}$ & $\begin{array}{l}\% \text { of AT- } \\
\text { rich repeats }\end{array}$ & No. of satellites \\
\hline A. racemosus & 20 & $0.53-1.23$ & 18.18 & $20 \mathrm{~m}$ & 6 & 14.30 & 4 & 16.83 & 2 in DAPI \\
\hline A. officinalis & 22 & $0.77-1.58$ & 24.66 & $22 \mathrm{~m}$ & 3 & 5.13 & 4 & 16.04 & - \\
\hline A. setaceus & 20 & $0.48-1.47$ & 18.50 & $20 \mathrm{~m}$ & 6 & 25.18 & 8 & 13.92 & 2 in Orcein and CMA \\
\hline
\end{tabular}

$\mathrm{m}=$ metacentric chromosomes

Table 2. Compilation of RAPD analysis in three species of Asparagus L.

\begin{tabular}{|c|c|c|c|c|c|c|}
\hline $\begin{array}{l}\text { Primer } \\
\text { codes }\end{array}$ & $\begin{array}{l}\text { Size ranges } \\
\text { (bp) }\end{array}$ & $\begin{array}{l}\text { Total } \\
\text { bands }\end{array}$ & $\begin{array}{c}\text { Common } \\
\text { bands } \\
\text { (bp) }\end{array}$ & $\begin{array}{c}\text { Polymorphic } \\
\text { bands } \\
\text { (bp) }\end{array}$ & Unique bands (bp) & $\begin{array}{l}\text { Polymorphism } \\
(\%)\end{array}$ \\
\hline OPG-3 & $300-2500$ & 14 & - & 14 & $\begin{array}{l}750,600 \text { in } A . \text { racemosus, } 2500,1500,1250,1000,700,450 \text { in } A . \\
\text { officinalis, } 1600,1100 \text { in } A \text {. setaceus }\end{array}$ & 100 \\
\hline OPG-6 & $200-2900$ & 16 & - & 16 & $\begin{array}{l}2900,2200,1500,1200,950,650,550,350,200 \text { in } A . \text { racemosus, } \\
1600,1400,1300,1100,600,500,300 \text { in } A . \text { setaceus }\end{array}$ & 100 \\
\hline OPG-9 & $250-2000$ & 8 & - & 8 & $\begin{array}{l}1500,500 \text { in } A . \text { racemosus, } 2000,1200,750,250 \text { in } A . \text { officinalis, } \\
1400 \text { in } A . \text { setaceus }\end{array}$ & 100 \\
\hline Primer-3 & $600-4000$ & 9 & - & 9 & $\begin{array}{l}3000,2500,2000,1500,1300,600 \text { in } \text { A. officinalis, } 2800,1400 \\
\text { in A. setaceus }\end{array}$ & 100 \\
\hline & $200-4000$ & 47 & - & 47 & & 100 \\
\hline
\end{tabular}

fined to the terminal region but rather distributed along the chromosomes. The possible reason for these entirely fluoresced chromosomes was tandem duplication of GCrich repeats along the length (Khatun and Alam 2010, Sultana and Alam 2007, Mahbub et al. 2007).

In A. officinalis, the percentage of GC-rich repeats was 5.13 (Table 1). The GC-rich percentage is about three times more in $A$. racemosus and about five times more in A. setaceus (Table 1). Therefore, the percentage of GC-rich repeats is an important karyotypic criterion of these three species.

Different DAPI-banding patterns were found in three Asparagus species as well. In $A$. racemosus, two chromosomes of pair X were entirely fluoresced while members of pair III were almost entirely fluoresced (Figs. 7, 16). One member of pair II, V, and XI were entirely fluoresced in A. officinalis (Figs. 8, 17). However, no entirely DAPI-fluoresced chromosome was found in A. setaceus (Figs. 9, 18). This banding pattern revealed that the ATrich areas of certain chromosomes in A. racemosus and A. officinalis had been tandemly duplicated, whereas such duplication was not happened in any chromosomes of $A$. setaceus.

\section{RAPD analysis}

DNA from three Asparagus species was isolated to study RAPD with four oligonucleotide primers. The four primers generated in total 47 distinct bands with $100 \%$ polymorphism. These three species did not share any common fragments of DNA in four RAPD primers (Figs. 19-22, Table 2). Several unique fragments were observed in three Asparagus species with four primers. Such as (i) in primer OPG-3, 750, 600 bp in A. racemo-

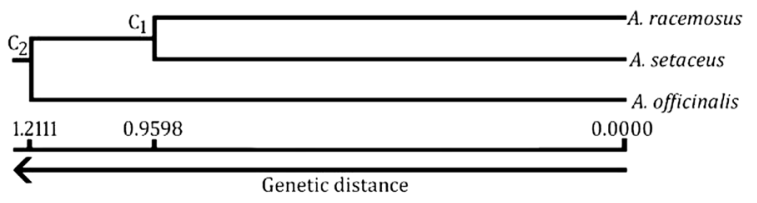

Fig. 23. UPGMA dendrogram based on Nei's (1972) genetic distance summarizing the data on differentiation between three species of Asparagus by RAPD analysis.

sus, 2500, 1500, 1250, 1000, 700, $450 \mathrm{bp}$ in A. officinalis and $1600,1100 \mathrm{bp}$ in $A$. setaceus, (ii) in primer OPG-6, 2900, 2200, 1500, 1200, 950, 650, 550, 350, $200 \mathrm{bp}$ in $A$. racemosus and 1600, 1400, 1300, 1100, 600, 500, $300 \mathrm{bp}$ in $A$. setaceus (iii) in primer OPG-9, $1500,500 \mathrm{bp}$ in A. racemosus, 2000, 1200, 750, $250 \mathrm{bp}$ in A. officinalis and $1400 \mathrm{bp}$ in $A$. setaceus (iv) in primer-3, 3000, 2500, 2000, 1500, 1300, 600 bp in A. officinalis and 2800, $1400 \mathrm{bp}$ in $A$. setaceus (Table 2). The term unique sequence means that the sequence found in a species with a certain primer was absent in other species (Table 2). The unique bands were stable, reproducible and specific, thus could be used as a tool for characterization. In the earlier literature, there was no information about unique RAPD band (Ii et al. 2012, Singh et al. 2013, Kumar et al. 2016). Therefore, the use of unique RAPD band as characterization tool for Asparagus spp. is a pioneer approach.

Genetic relationships among three Asparagus species

The values of pair-wise Nei's (1972) genetic distances were analyzed by using computer software "popgene32." The data segregated the three species in two clusters, $A$. racemosus and $A$. setaceus were placed in cluster 1 with genetic distance 0.9598 , whereas A. officinalis placed 
alone in cluster 2 with genetic distance 1.2111 (Fig. 23). The data clearly indicated the diverse genomic value of the three Asparagus species which correlated with the RAPD data (Table 2).

The foregoing discussion revealed that the three $A s$ paragus species have diverse orcein-, CMA-, and DAPIkaryotype with different RAPD-banding pattern. Therefore, the three Asparagus species could be characterized authentically with the help of combined cytogenetical and molecular data.

\section{Acknowledgements}

This research was partly supported by a grant from the Ministry of Science and Technology, People's Republic of Bangladesh, University Grants Commission of Bangladesh and Chromosome Research Centre, University of Dhaka, Bangladesh.

\section{References}

Ahmed, Z. U., Begum, Z. N. T., Hassan, M. A., Khondker, M., Kabir, S. M. H., Ahmad, M., Ahmed, A. T. A., Rahman, A. K. A. and Haque, E. U. 2007. Encyclopedia of Flora and Fauna of Bangladesh, Angiosperms: Monocotyledons, (Agavaceae-Najadaceae). Asiatic Society of Bangladesh, Dhaka.

Alam, Sk. S. and Kondo, K. 1995. Differential staining with Orcein, Giemsa, CMA, and DAPI for comparative chromosome study of 12 species of Australian Drosera (Droseraceae). Am. J. Bot. 82: 1278-1286.

Bered, F., Terra, T. F., Spellmeier, M. and Neto, J. F. B. 2005. Genetic variation among and within sweet corn populations detected by RAPD and SSR markers. Crop Breed. Appl. Biotech. 5: 418-425.

Camadro, E. L. 1994. Second meiotic division restitution (SDR) 2n pollen formation in diploid and hexaploid species of Asparagus. Genet. Resour. Crop Evol. 41: 1-7.

Castro, P., Gil, J., Cabrera, A. and Moreno, R. 2013. Assessment of genetic diversity and phylogenetic relationships in Asparagus species related to Asparagus officinalis. Genet. Resour. Crop Evol. 60: 1275-1288.

Deng, C. L., Qin, R. Y., Wang, N. N., Cao, Y., Gao, J., Gao, W. J. and Lu, L. D. 2012. Karyotype of Asparagus by physical mapping of 45S and 5S rDNA by FISH. J. Genet. 91: 209-212.

Doyle, J. J. and Doyle, J. L. 1987. A rapid DNA isolation procedure from small quantities of fresh leaf tissues. Phytochem. Bull. 19: $11-15$.

Garabadu, D. and Krishnamurthy, S. 2014. Asparagus racemosus attenuates anxiety-like behavior in experimental animal models. Cell. Mol. Neurobiol. 34: 511-521.

Ii, Y., Uragami, A., Uno, Y., Kanechi, M. and Inagaki, N. 2012. RAPD-based analysis of differences between male and female genotypes of Asparagus officinalis. Hort. Sci. 39: 33-37.

Kamat, J. P., Boloor, K. K., Devasagayam, T. P. and Venkatachalam, S. R. 2000. Antioxidant properties of Asparagus racemosus against damage induced by gamma-radiation in rat liver mitochondria. J. Ethnopharmacol. 71: 425-435.

Khatun, M. and Alam, Sk. S. 2010. Confirmation of species status of Corchorus trilocularis and C. pseudo-olitorius by differential chromosome banding and isozyme assay. Cytologia 75: 83-88.

Khatun, M., Sultana, S. S., Ara, H., Islam, M. N. and Alam, Sk. S. 2011. Differential chromosome banding and isozyme assay of three Corchorus spp. Cytologia 76: 27-32.
Kondo, K., Smirnov, S. V., Kucev, M. and Shimakov, A. I. 2014. A chromosome study in Asparagus officinalis L. in Mt. Altai. Chromosome Bot. 9: 123-124.

Krasnikov, A. A. and Shaulo, D. N. 1990. Chromosome numbers of representative of some families of vascular plants in the flora of the Novosibirsk region. II. Bot. Zurn. 75: 118-120.

Kumar, M., Naik, P. K., Sarla. and Chhokar, V. 2016. Genetic variations in Asparagus racemosus, an endangered medicinal herb endemic to India using RAPD markers. Br. Biotechnol. J. 10: 1-11.

La Cour, L. F. 1952. Chromosome counts of species and varieties of garden plants. Annu. Rep. John Innes Hortic. Inst. 42: 23.

Ma, X. H., Qin, R. L. and Xing, W. B. 1985. Chromosome observation of twenty species of drug plants in Xing Jiang. Acta Bot. Bor. Occ. Sin. 5: 149-154.

Mahbub, M. N., Rahman, A. N. M. R. B. and Alam, Sk. S. 2007. Development of marker chromosomes in three varieties of Vigna radiata (Fabaceae). Cytologia 72: 221-225.

Mehra, P. N. and Malik, C. P. 1961. Cytology of Indian medicinal plants III, Some Liliaceous drugs. In: Proceedings of the 48th Indian Science Congress, Part 3, Roorkee. pp. 293-294.

Melo, N. F. and Guerra, M. 2001. Karyotypic stability in Asparagus (Asparagus officinalis L.) cultivars revealed by rDNA in situ hybridization. Cytologia 66: 127-131.

Muhkopadhyay, S. and Ray, S. 2013. Chromosome and marker-based genome analysis of different species of Asparagus. Cytologia 78: 425-437.

Nei, M. 1972. Genetic distance between populations. Am. Nat. 106: 283-292.

Osaka, S. 1938. On the chromosome numbers of some Asparagus species. Commem. Pap. Agron. M. Akemine 1938: 187-190.

Rudall, P. J., Engleman, M., Hanson, L. and Chase, M. W. 1998. Embryology, cytology and systematics of Hemiphylacus, Asparagus and Anemarrhena (Asparagales). Plant Syst. Evol. 211: 181-199.

Sairam, K., Priyambada, S., Aryya, N. C. and Goel, R. K. 2003. Gastroduodenal ulcer protective activity of Asparagus racemosus: an experimental, biochemical and histological study. J. Ethnopharmacol. 86: 1-10.

Sastry, M. 1981. Chromosome studies and DNA estimation in Asparagus sp. In: Proceedings of the $68^{\text {th }}$ Indian Science Congress, Part 3, Varanasi. p. 85.

Schweizer, D. 1976. Reverse fluorescent chromosome banding with chromomycin and DAPI. Chromosoma 58: 307-324.

Sharma, A. K. and Bhattacharya, B. 1957. Cytology of six species of Asparagus and Lilium. Phyton 8: 1-12.

Sheidai, M. and Inamdar, A. C. 1993. B-Chromosomes in Asparagus L. Nucleus 36: 141-144.

Singh, A. 2014. Asparagus racemosus and its phytoconstituents; an updated review. Asian J. Biochem. Pharm. Res. 4: 230-240.

Singh, A., Rai, V. P., Singh, M., Singh, A. K. and Sinha, B. 2013. Molecular diversity analysis of Asparagus racemosus and its adulterants using random amplified polymorphic DNA (RAPD). J. Med. Plant Res. 7: 1050-1056.

Sinha, S. S. N., Prasad, R. and Keswani, R. 1972. Cytological studies in some medicinal plants of Chhotanagpur. In: Proceedings of the 59th Indian Science Congress, Part 3, Calcutta. p. 349.

Subramanian, D. 1973. Cytological investigations in Haemanthus coccineus L., Asparagus racemosus Willd. and Yucca gloriosa Linn. In: Proceedings of the $60^{\text {th }}$ Indian Science Congress, Part 3, Chandigarth. pp. 323-324.

Sultana, S. S. and Alam, Sk. S. 2007. Differential fluorescent chromosome banding of Solanum nigrum L. and Solanum villosum L. from Bangladesh. Cytologia 72: 213-219.

Sultana, S. S. and Alam, Sk. S. 2016. Differential fluorescent banding in 11 varieties of Gossypium hirsutum L. from Bangladesh. Cytologia 81: 111-117.

Sultana, S. S., Ara, H. and Alam, Sk. S. 2011. Karyotype analysis 
with orcein and CMA in two species of Alocasia (Schott) G. Don. (Araceae). Bangladesh J. Bot. 40: 53-56.

Thombre, M. V. 1959. Chromosome numbers in some common flowering plants. Curr. Sci. 28: 206-207.

Venkatesan, N., Thiyagarajan, V., Narayanan, S., Arul, A., Raja, S., Gurusamy, S., Kumar, V., Rajarajan, T. and Perianayagam, J. B. 2005. Anti-diarrhoeal potential of Asparagus racemosus wild root extracts in laboratory animals. J. Pharm. Pharm. Sci. 8: $39-45$.

Venkateswarlu, J. and Raju, C. S. K. 1957. Cytological studies in the genus Asparagus. In: Proceedings of the 44th Indian Science
Congress, Part 3, Calcutta. pp. 260-261.

Warrier, P. K., Nambiar, V. P. K. and Ganapathy, P. M. 2001. Some important medicinal plants of the western ghats, India: a profile. International Development Research Centre, New Delhi.

Williams, J. G. K., Kubelik, A. R., Livak, K. J., Rafalski, J. A. and Tingey, S. V. 1990. DNA polymorphisms amplified by arbitrary primers are useful as genetic markers. Nucleic Acids Res. 18: 6531-6535.

Zaman, M. Y. and Alam, Sk. S. 2009. Karyotype diversity in three cultivars of Momordica charantia L. Cytologia 74: 473-478. 